\title{
COMPETITIVENESS ASSESSMENT FOR REAL ESTATE ENTERPRISES IN CHINA: A MODEL-PROCEDURE
}

\author{
Xiaoling ZHANG ${ }^{1}$, Liyin SHEN ${ }^{2}$, Yuzhe WU ${ }^{3}$ and Linda C. N. FAN ${ }^{4}$ \\ ${ }^{1}$ Department of Building and Real Estate, The Hong Kong Polytechnic University, \\ Hong Kong, China \\ E-mail: lingxiaoxiao02@hotmail.com \\ 2 Department of Building and Real Estate, The Hong Kong Polytechnic University, \\ Hong Kong, China \\ E-mail: bsshen@inet.polyu.edu.hk \\ 3 Department of Land Administration, Institute of Land Science and Property Management, \\ Zhejiang University, 258 Kaixuan Road, Hangzhou 310029, China \\ E-mail: wuyuzhe@zju.edu.cn \\ ${ }^{4}$ Department of Building and Real Estate, The Hong Kong Polytechnic University, \\ Hong Kong, China \\ E-mail: bsfan@inet.polyu.edu.hk
}

Received 6 February 2009; accepted 2 June 2009

\begin{abstract}
China's accession to the World Trade Organization (WTO) in 2001 has allowed both domestic and overseas real estate enterprises to compete under the same market conditions. This has led to a more rigorous competition in the Chinese real estate market. Understanding this challenge is essential as it enables real estate enterprises to assess their competitiveness properly, and therefore adapt to their competition environment by applying adequate methods to improve their competitiveness. This paper presents an understanding on the applicability of various established competitiveness assessment methods. The characteristics of real estate firms are also presented with the appreciation of the Chinese environment. The study investigates the applicability of various established competitiveness assessment methods for real estate organizations in China considering the characteristics of real estate industry and the comments of the interviewees. The understanding on this applicability leads to the development of a model-procedure for assessing the competitiveness of real estate firms. The model-procedure employs various assessment methods in different stages in the process of examining the competitiveness of real estate businesses. The effectiveness of the application of the model-procedure is evidenced through discussions with senior professionals. Then a case study is presented to illustrate how the model-procedure can be applied. The findings of the study provide valuable references to study competitiveness assessment in other country's real estate industries.
\end{abstract}

KEYWORDS: Competitiveness assessment; Model-procedure; Real estate enterprises (REEs); Assessing method; Chinese real estate industry

\section{INTRODUCTION}

Previous studies have addressed exclusively the subject of competitiveness, which can be classified into several categories of competitiveness theories. The resource-based competitiveness theory considers the unique resources as organizational core competitiveness (Wernerfelt, 1984). The 'diamond' competitiveness framework introduced by Porter (1990) is widely adopted for analyzing the competitiveness at both national and industrial 
level. Drew and Skitmore (1997) introduced a multiple regression model for investigating the organizational competitiveness in competing for a construction contract. There are still other models for analyzing business competitiveness. Walsh and Linton (2001) developed a framework for analyzing an organization's competitiveness from the perspectives of technical competencies and managerial capabilities in manufacturing industry. Bogner et al. (2002) built a competitiveness conceptualization framework to present the dynamic relationship between competence and competitive advantage in business environment. Sirikrai and Tang (2006) presented an Analysis Hierarchy Process (AHP) model to formulate important performance indicators when assessing industrial competitiveness. The Institute for Management Development (IMD) and the World Economic Forum adopts "World Competitiveness Scorecard" in ranking the top 22 countries as best Organization for Economic Cooperation and Development (OECD) (IMD, 2004). The scorecard adopts 378 indicators which are aggregated to five groups: internationalization, science and technology, management, infrastructure and people, education and skills.

Whilst these methods have been developed for application in different environments, there is a question remaining unanswered: how to choose an effective approach which can help understand properly the competitiveness of different types of companies such as real estate firms? As individual firms are structured and focused differently, there exists a challenge for choosing proper measures to identify the competitiveness for different types of firms. Another major challenge to the understanding organizational competitiveness is the dynamic market environment such as in real estate industry. There are more uncertainties and changes in a market which is not mature and has not been well developed such as the Chinese real estate market. The understanding on these challenges is essential as it ena- bles organizations to choose effective method in assessing their competitiveness properly.

China's accession to the WTO in 2001 marks the beginning of a new era of China's opening-up to the world. This development benefits the Chinese businesses including real estate enterprises from participating more actively and freely in international business activities. Increasing number of Chinese contractors and real estate developers has started to operate overseas business. For example, China Overseas Property has been undertaking major property development projects in a number of Middle East cities such as Dubai. The development of China's accession to WTO on the other hand presents challenges to the Chinese domestic real estate firms as increasing foreign products and services have been entering into the China real estate market. For example, by the end of October 2006, the number of foreign real estate entrepreneurs in Shanghai accounts for $7 \%$ of the city's total number of real estate enterprises; and their registered capital accounts for $27 \%$ of the total registered capital in the local real estate industry (Zhang, 2007). The opportunities and challenges encountered by the Chinese real estate firms request them to adequately understand their competitive position.

The proper analysis on competitiveness will help a firm (both domestic and overseas) in the Chinese real estate market to know whether it has competitive advantage over its competitors within the business environment. The assessment results can therefore be valuable information for organizations to make decisions of identifying competition strategy and applying adequate methods to improve their competitiveness where necessary. It is therefore the major objective of this paper to understand the characteristics of various assessment methods for organizational competitiveness and identify the methods effective for enabling real estate firms to understand their competitiveness with particular reference to the Chinese business environment. 


\section{TYPICAL METHODS USED FOR ASSESSING ORGANIZATION COMPETITIVENESS}

\section{Indicator approaches (IA)}

Many research works have been conducted in developing various indicators for examining organizational competitiveness, which can be called indicator approach (IA). The review on previous works has identified 91 relevant works published during the period from 1973 to 2007, which led to the identification of 24 typical competitiveness indicators as shown in Table 1 and Figure 1. The frequency of adopting these indicators among the literatures is illustrated in Figure 1, which indicates to cer- tain extent different effectiveness in adopting these indicators. For example, the indicator I12"innovation action" has been addressed in 18 works out of the 91 identified works and the indicator I16 "market process" in 14 references.

Indicator approach examines organizational competitiveness qualitatively. Whilst these are various indicator approaches suggested in the literatures, according to the attributes considered, these indicator approaches can be broadly divided into two groups, namely, single attribute index measure and multi-attributes index measure. There are many attributes applied to assess organizational competitiveness in a single aspect, for example, profitability,

Table 1. Typical indicator for measuring organization competitiveness

Indicators

\begin{tabular}{|c|c|c|c|}
\hline $\mathrm{I}_{1}-$ Brand Assets & $\mathrm{I}_{7}-$ Entrepreneurial Quality & $\begin{array}{c}\mathrm{I}_{13}-\underset{\text { Information }}{\text { Technology }} \\
\text { Techolo }\end{array}$ & $\begin{array}{c}\mathrm{I}_{19}-\text { Production } \\
\text { Efficiency }\end{array}$ \\
\hline $\mathrm{I}_{2}-$ Core Competence & $\mathrm{I}_{8}-$ Financial Assets & $\mathrm{I}_{14}-$ Knowledge Assets & $\mathrm{I}_{20}-$ Productivity \\
\hline $\mathrm{I}_{3}-$ Cost Advantage & $\mathrm{I}_{9}-$ Firm Structure & $\mathrm{I}_{15}-\begin{array}{l}\text { Manufacture } \\
\text { Capacity }\end{array}$ & $\mathrm{I}_{21}$ - Profitability \\
\hline $\mathrm{I}_{4}-$ Cultural Assets & $\mathrm{I}_{10}-$ Human Resources & $\mathrm{I}_{16}-$ Market Process & $\mathrm{I}_{22}-$ Quality Control \\
\hline $\begin{aligned} & \mathrm{I}_{5}- \text { Customer } \\
& \text { Satisfaction }\end{aligned}$ & 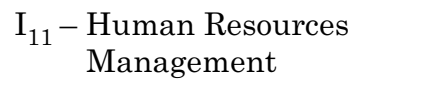 & $\mathrm{I}_{17}-$ Market Share & $\begin{array}{c}\mathrm{I}_{23}-\text { Uniqueness } \\
\text { of Product }\end{array}$ \\
\hline $\begin{array}{l}\mathrm{I}_{6}-\underset{\text { Distinctive }}{\text { Competitive Strategy }}\end{array}$ & $\mathrm{I}_{12}-$ Innovation Action & $\begin{array}{c}\mathrm{I}_{18}-\text { Organization } \\
\text { learning }\end{array}$ & $\mathrm{I}_{24}-$ Value Creation \\
\hline
\end{tabular}

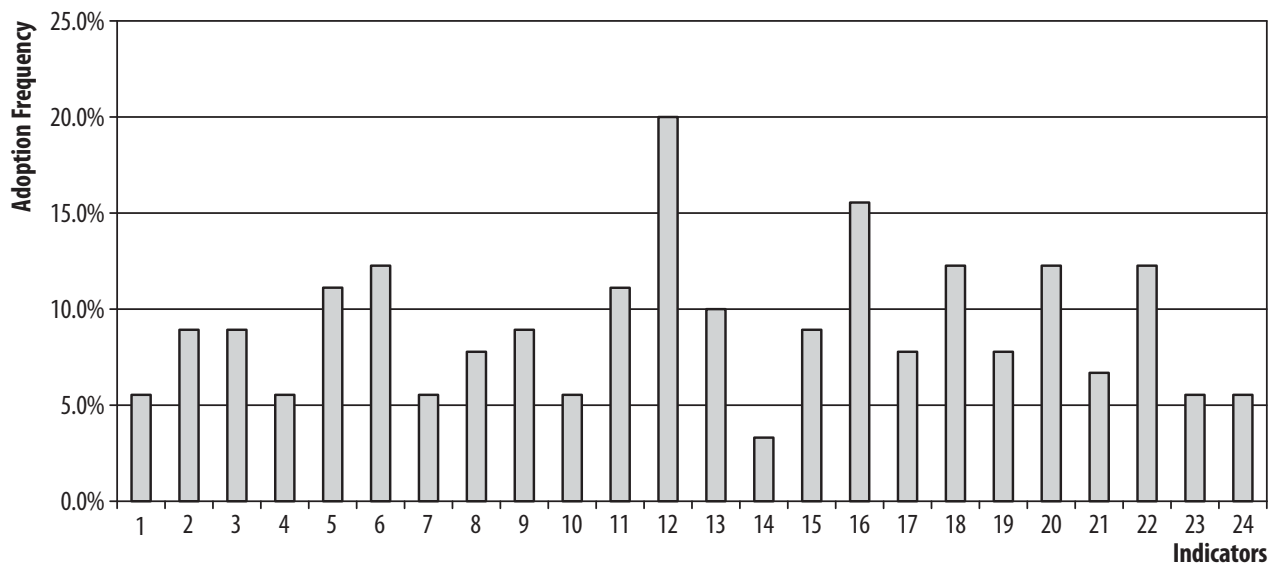

Figure 1. The adoption frequency of competitiveness indicators in the literatures 
firm structure, financial assets, and knowledge assets (Rappaport, 1983; Feurer and Chaharbaghi, 1994). The practice of examining single aspect of organizational competitiveness can be called as single indicator approaches (SIA). Nevertheless, the limitation of single-attribute index method can be appreciated. For example, it can not indicate an organization's overall competitiveness. This leads to the development of multiple-indicators index approach for measuring an organization's competitiveness.

Multiple indicators are often used collectively to examine an organization's competitiveness from different perspectives. It helps to understand an organization's overall competitiveness. Weighted values are usually used for measuring the contribution of multiple indicators, and this method is called Weighted Summation (WS) method. WS method has been widely used when multi-attributes are considered in assessing the performance of an objective variable (Jansen, 1992). The principle of WS is to employ a quantitative model, as shown below, to generate a weighted value:

$$
T V=\sum_{i=1}^{N} W_{i} \times V\left(A_{i}\right)
$$

where: $T V$ is the weighted value or total value of an objective variable (for example, total competitiveness); $A_{i}(i=1,2,3, \ldots \mathrm{N})$ is one of the multiple attributes used for assessing the $T V ; W_{i}$ is the weighting value of the attribute $A_{i}$, and $V\left(A_{i}\right)$ is the performance value of $A_{i}$.

Model (1) has been widely adopted in the many areas (Hobbs and Meier, 2000). A typical application of the weighted summation approach is the publication of the World Competitiveness Yearbook (WCY) by IMD (2004).

In many studies, indicator approaches (IA) and weighted summation (WS) model, are used in combination. Shen et al. (2006) adopted this combination and introduced the model of Key Competitiveness Indicators (KCIs) for examining contractor's key competitiveness in construction industry through establishing rel- ative significance between various indicators. Using the KCI model can generate an index value for each competitiveness indicator, and KCIs are identified according to the index values between individual indicators.

\section{Modeling approaches}

There are other modeling approaches introduced in previous studies for assessing organizational competitiveness. The following discussion presents several major approaches.

\section{(1) Value Chain Model (VCM)}

Porter and Millar (1985) defined an organization's production process as a VCM in order to examine organizational competitiveness. This value chain includes five primary processed activities: inbound logistics, operation, outbound logistics, marketing and services, and four support activities: firm infrastructure, human resource management, technology development and procurement. Value chain model suggests that a firm's competitiveness comes from all these value chain activities. Thus each activity in the chain needs to be analyzed in order to capture organization's competitiveness.

\section{(2) Portfolio matrix model (PMM)}

PMM was developed during the 1970s and early 1980 s by a number of leading consulting firms for helping managers better understand the competitive portfolio of businesses. The two dimensions in the matrix model include industry attractiveness and business strength. Industry attractiveness is measured by external factors such as market size and market growth rate, and business strength by internal factors such as market share, profitability and customer service (Hax and Majluf, 1983). By using the PMM, organizational competitiveness is measured in an AttractivenessStrength coordinate system (Macmillan and Tampoe, 2000).

\section{(3) Competence pyramid model (CPM)}

CPM was introduced by Walsh and Linton (2001) for analyzing an organization's competi- 
tiveness in manufacturing industry. The model considers organizational competence in four categories: materials, fabrication and assembly, knowledge-based services, and knowledgeembed services. Each category represents one of the faces of a "pyramid". Each pyramid face includes two components: managerial capability at the pinnacle of the pyramid, and technical competency segment at the base of the pyramid (Hulshoff et al., 1998).

\section{(4) Enterprise Model (EM)}

Hatten and Rosenthal (1999) presented an enterprise model (EM) to exhibit business functions and processes for understanding organizational competitiveness. The model presents a schematic network of business functions and processes where business competitiveness rests in. In the schematic network, vertical and horizontal arrows were used, in which vertical arrows represent business functions, for example, marketing, research and development (R\&D), operations, and finance; and the horizontal arrows represented business processes such as product development, order acquisition and post-sale service. EM forms a platform for assessing enterprise-wide alignment and identifying opportunities for performance improvement.

\section{(5) Industrial competitiveness model (ICM)}

The study by Oral (1993) presents a competitiveness model, called industrial compet- itiveness model (ICM), to measure a manufacture's competitiveness at industrial level. In this model, competitiveness is expressed as a mathematical function of the firm's industry mastery position which is indicated by four factors: current position, current comparative position, potential position, and potential comparative position.

\section{(6) Weibull model (WM)}

Weibull model (WM) was introduced by Weibull (1951), presenting a method for assessing reliability in the discipline of physics. It is a well recognized model and has been widely used in research. Lin et al. (2001) studied the applicability of this model for assessing the competitiveness of manufacturing enterprises at a particular point of time in life cycle, and a typical case study was demonstrated on the basis.

Following the above discussions, the existing methods for assessing organizational competitiveness can be grouped in a diagrammatical structure, as shown in Figure 2. Individual methods bear different characteristics. Proper choice betwe en these methods for application is important to ensure proper assessment on organizational competitiveness. The study in the next section of this paper will discuss the suitability of applying these methods for assessing the organizational competitiveness within the context of real estate industry.

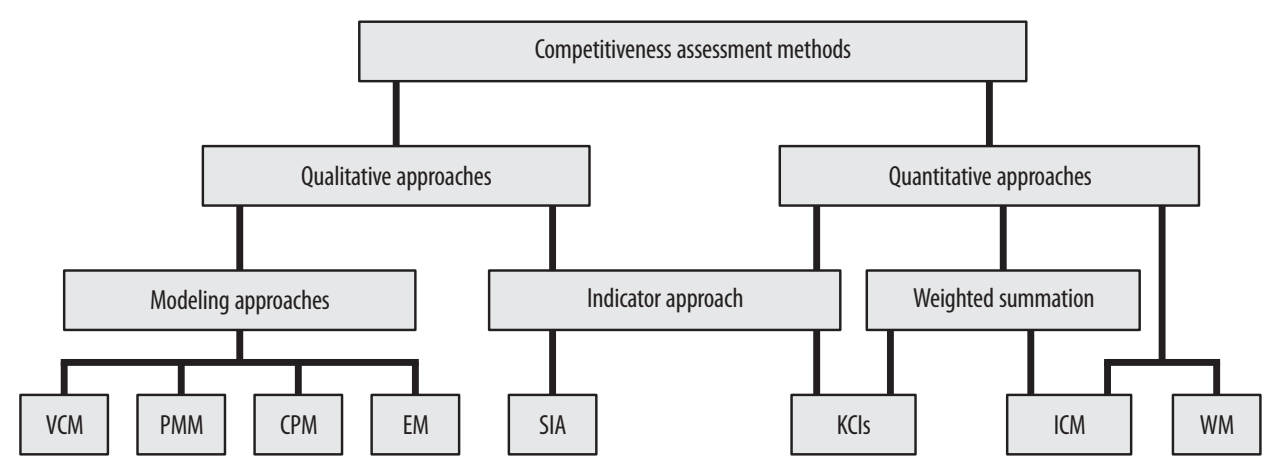

Figure 2. The composition of typical assessment methods for organizational competitiveness 


\section{ASSESSING THE COMPETITIVENESS OF REAL ESTATE ENTERPRISES (REES)}

The discussions in the previous section provide a profile of the existing methods for assessing organizational competitiveness. This section aims to examine the applicability of various competitiveness assessment methods for real estate enterprises. As the applicability of different methods varies under different application conditions, selection of an assessment method must consider the characteristics of the organization concerned. Organizations with different industrial backgrounds or under different market environments will be viewed differently when different competitiveness assessment methods are applied. Therefore, it is important to understand the characteristics of REEs in order to analyze the applicability of various assessment methods for this type of organizations.

\section{Research Data and methods}

Research data were collected through multiple approaches, including the review on the typical existing methodologies in the literature. The literature review also highlighted the insufficiency of the data only collected from literatures, thus more data supporting the analysis of the applicability of various assessment methods are needed accordingly. Therefore, practical survey was adopted to collect more data. The objective of the empirical part is not to test the applicability of the existing approaches but rather to study more comprehension on the current practice of real estates' competitiveness.

The data used for supporting the analysis in this section are from a practical survey to the real estate industry in China, supplemented by literature references. In the survey, 20 senior managers are selected from real estate enterprises to participate in interviews, including 10 vice general manager, 5 general managers, and 5 department managers. These enterprises are located in the Yangtze River
Delta (including Shanghai, Hangzhou, Nanjing, and Suzhou) and Beijing. The interview works were conducted in August and September in 2008. The semi-structured interviews were adopted through open-ended questions whilst each interview was controlled within 3 hours. The interview questions are designed to help understand (1) what are the typical characteristics of REEs in comparing to other type of business? (2) what are the competencies that individual interviewees considered that their organizations have? (3) what procedures should be used for competitiveness analysis for REEs? and (4) How applicable are the established competitiveness assessment methods discussed before for REEs with reference to the Chinese context.

Survey study was focused on group interviews and site visits, which were held within China Vanke Company in Hangzhou, Shenzhen and Beijing. Valuable comments and opinions were recorded comprehensively for supporting analysis. Furthermore, the relevant document materials in the surveyed companies were collected to investigate the correlation between the theoretical framework and practical experiences. Real estate professionals participating in the interviews were carefully identified to ensure that they had a good understanding of and experience in conducting real estate business from different perspectives. As interview questions were designed as semi-structure questions, it allows the interview discussions flexible and constructive. Thus the information collected from the interviews is considered valid. The collected data would be arranged, analyzed and input into the next application phase.

\section{The characteristics of Real estate enterprises}

It is well appreciated that different types of enterprises have different characteristics and effective border in their business (Committee of Donor Agencies for Small Enterprise Development, 1995). The characteristics of real 
estate enterprises can be demonstrated in the following areas.

- Real estate projects have strong local characters, thus each real estate project has unique features. Real estate products are different in locations, shapes and application of materials. These differences present difficulties in promoting standardization for real estate products (Weimer and Hoyt, 1939). Thus REEs need to spend special efforts in planning each individual project.

- Real estate businesses engage complicated and long contractual process with various other businesses. The production process in real estate business embraces various lengthy activities, typically including site acquisition, site survey and formation, securing planning consent, finance arrangements, design, construction, and marketing (Barrett et al., 1978; Healey, 1994). Each individual process needs to be undertaken by cooperating between real estate developers and various other enterprises and professionals, including suppliers, design firms, construction firms, property management companies and others (Jin, 2003).

- REEs are capital-intensive. The funds needed for the development of a real estate project are in large scale mainly for land acquisition and construction. REEs have to approach various financing channels to secure sufficient finance for operating business activities (Wu, 2002). This is echoed by interviewees including the managers in Vanke (China Vanke Co., Ltd. is principally engaged in the real estate industry and develops residential buildings in 28 cities throughout China and provides property management services.), Greentown (Greentown China Holdings Limited, located in Hangzhou, Zhejiang province, is one of the Top 10 real estate enterprises in China), suggest- ing that banking is the most important financial channel for their businesses.

- REEs are resource-intensive. REEs possess two types of major resources, namely, land reserves and professional human resources. Land is the premise and primary condition in operating business for a REE (Liu, 2004). In the absence of adequate land reserves, a real estate developer will lose business opportunities, and its business may have to be suspended. In particular, with the limited land left for urban development, land resource in urban area becomes scarce and expensive. Real estate firms with no land reserves in urban area will find themselves in disadvantages position. Therefore, proper strategies for reserving land resources are very important to REEs. On the other hand, the complicated development process for real estate projects requests for the employment of many types of professionals and technical personnel. These professionals are expensive and their expertise crosses multiple disciplines, including the knowledge of obtaining land-use right, planning and design, project financing, project management and marketing management (Cong and Wang, 2004).

- REEs' business is subject to high risk but at the same time with expectation of high return (Tay and Tay, 2007). Real estate projects usually engage a long term of production process. This lengthy process presents various types of risks such as changes in governmental policies, changes in interest rates, changes in market environment (van der Krabben and Lambooy, 1993). In the interview survey, the manager from Greentown Developer pointed out three typical risks for REEs in China: (1) the fluctuation in economic environment and real estate market, which can bring REEs with 
loss; (2) the change of financial interest rates, which leads to the cost increase; and (3) the changes in the government's macro-regulation, which can cause risks to REEs. The resources invested in developing a real estate project are usually in large scale, thus the consequences will be substantial if risks.

\section{Applicability of competitiveness assessment methods for REEs}

The effectiveness of application of a specific competitiveness assessment method will depend upon whether the principles of the method are suitable to the characteristics of REEs. The following discussions are based on the understanding of various competitiveness assessment methods, the interviews with the real estate professionals and the characteristics of REEs which have been discussed above. Data was collected using focus group interviews. The interviews were conducted at the managerial level, involving two to four experienced real estate professionals. The interviews were incorporated with questions concerning the decision-making judgments of competitiveness assessment methodologies referring to their own practical experiences.

The comments raised from interview surveys are also incorporated into the analysis.

- Value chain approach (VCA)

The value chain model is considered suitable to find out the sources of competitiveness for REE businesses as a REE operates a complicated process which composes various value-added activities. Nevertheless, attention should be given that VCA has been considered traditionally effective in analyzing the competitiveness and activities of production enterprises (Chiang and Trappey, 2007), whereas REEs operate on service-type activities. The difference in business nature can be incorporated when VCA model is adopted for the application in real estate industry. In practice, VCA has already been used as one effective tool in seeking for the sources of competitiveness for REEs. This was also endorsed by the 10 interviewees.

- Portfolio matrix model (PMM)

PMM model is for measuring the competitiveness level between different business activities from perspective of attractiveness and strength. The interview discussions indicate that the model is reasonably effective for application in assessing competitiveness of REEs. By using PMM model, for example, REEs can select strategy by developing either high-end segment housing (e.g. villas, luxury flats or service apartment), medium-end segment (e.g. mass residential) or low-end segment (e.g. economic commodity housing). According to the strategy manager of Hangzhou Vanke, PMM model was effective owing to their own experience. Before 1992, Vanke was a multi-disciplinary business company, involving international trade, retails, mechanic \& electronic and printing. Having analyzed its attractiveness and strength among all its businesses, the company chose real estate industry for its longterm development business. By the end of $1990 \mathrm{~s}$, Vanke further decided to focus on the medium-end commodity housing as its only business segment, which helps it establish the leading role in China real estate industry (Mao, 2007).

- Enterprises model (EM)

EM helps organizations to identify competitive strategies by examining unique resources in the organizational functions and processes. It is considered applicable for REEs. As discussed previously that REEs are resource intensive, unique resources are particularly important to REEs. Individual REEs have to identify and build up such resources. In the interview discussion, the vice-president 
of Binjiang Real Estate Company echoed that EM model is effective to orient REEs' competitiveness. For example, Binjiang Real Estate Company identifies its good relationship with the local district government as its unique resources. This organization is located in Hangzhou of Zhejiang Province, with main business of luxury apartments as well as commercial properties. It was restructured ten years ago from a state-owned enterprise to a private firm, and it still keeps good relationship with the governmental departments which they used to work for. By using these resources, it is more accessible to land resources, which becomes its unique competitiveness in the market (Huang and $\mathrm{Wu}, 2005$ ).

- Single indicator approach (SIA)

This method suggests adopting one indicator for measuring an organization's competitiveness. It is applicable to measure organizational competitiveness from a specific dimension but not a holistic view. However, a REE's competitiveness is formed by many aspects, thus SIA is considered not effective in analyzing REEs' competitiveness, and this was agreed unanimously in the interview discussions.

- Weighted summation (WS) and Key competitiveness indicators (KCIs)

Both WS and KCIs methods adopt multiple competitiveness indicators and present a weighted index value for measuring organizational competitiveness. KCIs method has been used in construction industry for measuring contractors' competitiveness (Shen et al., 2006), which offers a valuable reference for assessing REEs' competitiveness. After a simple introduction of the WS and KCIs methods to the interviewees involved, the methods WS and KCIs are considered effective for understanding the key indicators in the process of the competitiveness assessment of real estate businesses.

- Industrial Competitiveness Model (ICM) ICM method presents a framework of integrating multiple attributes for assessing organizational competitiveness at an industry level through mathematical models. As for the macroscopic attributes, this method is considered not applicable for application in assessing real estate enterprise's competitiveness at enterprise level.

- Weibull model (WM)

Weibull model is introduced to assess the competitiveness level across an organization's life cycle in manufacture industry. The model is considered a good tool to assess REEs' competitiveness level at different stages in their life cycle. Although real estate industry in China is relatively new, several real estate firms in China, such as Vanke, have developed for more than 20 years by 2008 . The stage competitiveness assessment can help REEs identify its competitiveness level at different development stage. 11 interviewees in the survey also opined that it would be valuable for understanding stage competitiveness.

In the interview discussions, the interviewees are not only invited to comment on various existing methods in general, but also invited to indicate the level of applicability of each individual methods between effectively applicable, applicable and inappropriate. When this is added to the above discussions, the applicability of various competitiveness assessment methods for assessing REEs' competitiveness can be summarized in Table 2. It can be seen that the four typical methods IA, PMM KCIs and WS are considered effectively applicable, VCM, EM, and WM applicable, while ICM, SIA and CPM inappropriate. In addition, each of the methods focuses on different particular parts for competitiveness. 
Table 2. Summary on the applicability of competitiveness assessment methods for REEs

\begin{tabular}{llll}
\hline \multirow{2}{*}{ Assessment methods } & Applicability & & \\
\cline { 2 - 4 } & Effectively applicable & Applicable & Inappropriate \\
\hline Indicator approach (IA) & $\sqrt{ }$ & $\sqrt{ }$ \\
Value chain model (VCM) & & & \\
Portfolio matrix model (PMM) & $\sqrt{ }$ & $\sqrt{ }$ \\
Competence pyramid model (CPM) & & & \\
Enterprise model (EM) & & & \\
Single index approach (SIA) & $\sqrt{ }$ & $\sqrt{ }$ \\
Weighted summation model (WS) & $\sqrt{ }$ \\
Industrial competitiveness model (ICM) & & & \\
Weibull model (WM) & & & \\
Key competitiveness indicators (KCIs) & $\sqrt{ }$ & \\
\hline
\end{tabular}

\section{DEVELOPMENT OF A MODEL- PROCEDURE FOR ASSESSING SREES' COMPETITIVENESS}

The discussion in the previous section suggests that effectiveness in using the exiting methods in studying REEs' competitiveness varies. Even though some methods are considered effectively applicable, they only focus on some attributes. There is no such method between these established ones that can provide a holistic view of organizational competitiveness. It is therefore considered important and necessary to employ a new method that can incorporate the advantages of various existing methods in assessing REEs' competitiveness. As echoed by the interviewees that application should make use of the different strengths of individual methods, as no single method can help assess the overall competitiveness of REEs. Efforts in adopting the new method should employ different methods in combination. This new method is proposed as a model-procedure for competitiveness assessment for REEs. The constructive discussions with the interviewees in the study led to the identification of the following key procedures in undertaking competitiveness assessment for
REEs: (1) understand general competitiveness indicators; (2) select the core competitiveness indicators; (3) understand the sources for competitiveness; (4) evaluate the competitiveness level; and (5) identify the strategy for improving competitiveness.

These processes form a model-procedure, as shown in Figure 3. These procedures can be implemented by using the competitiveness assessment methods examined before. In particular, these methods identified as effectively applicable (IA, PMM, WS, KCIs) and applicable (VCM, EM, WM) should be applied. The guidelines and applied techniques of practicing these procedures are discussed using a case study in section 5 .

\section{APPLICATION OF THE MODEL- PROCEDURE: THE CASE OF CHINA VANKE}

This session is to discuss the applicability and advantages of using the model-procedure for assessing the competitiveness of real estate enterprises. A case of China Vanke is selected to fully demonstrate how to apply the modelprocedure into the real life practice. 


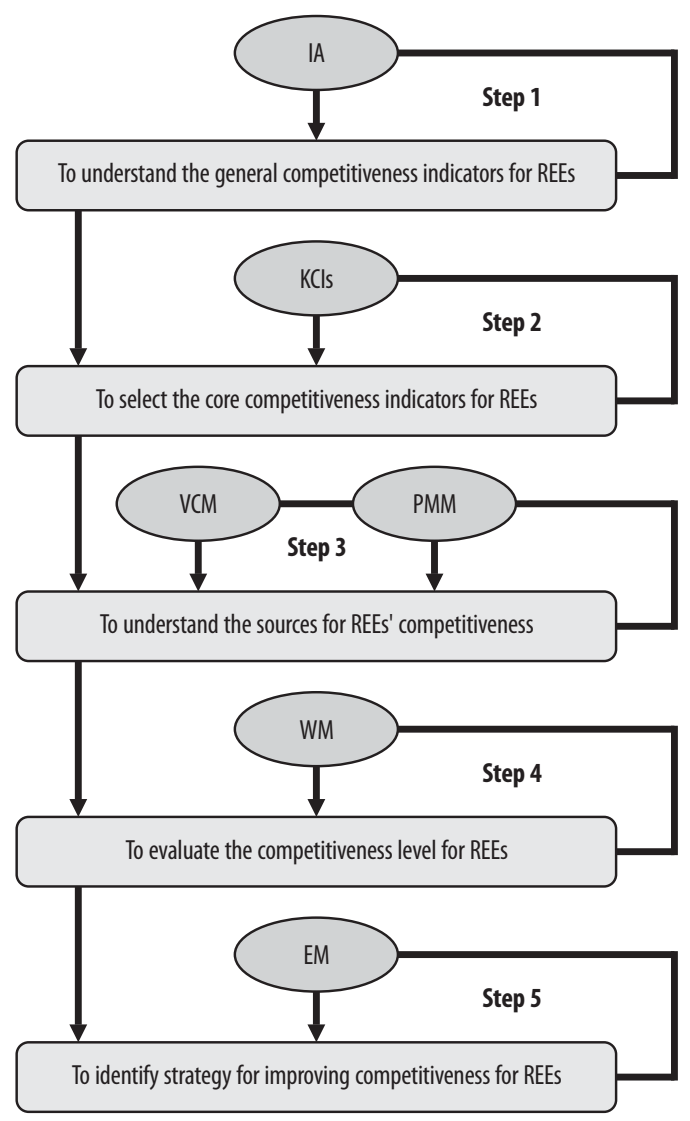

Figure 3. A model-procedures for assessing REEs' competitiveness

The advantages of the model-procedure can be identified as follows:

- It is a systematic flow-chart approach and develops an integrated analysis chain which incorporates the hands-on operations embodied in the existing practices;

- Have more clear understanding on the core competitiveness indicators for REEs;

- Have better understanding above where a REE own competitiveness, in other words, a REE can use the model to identify the sources of its competitiveness;

- A REE can assess its competitiveness by referring the model guidelines;

- The model also documents the actual and prospective operating strategies and provides alternative strategies for helping a REE to improve its competitiveness.

\section{Application of the model-procedure: the case of China Vanke}

China Vanke Company Limited (SZSE: 000002), headquartered in Shenzhen, Guangdong province, is the largest residential real estate developer in the People's Republic of China (PRC). It is engaged in developing, managing and selling of the properties across 28 cities in Pearl River Delta, Yangtze River Delta and Bohai-Rim Region, with the provision of investment trading, consultancy services and e-business. Up to now, China Vanke has built homes for over 90,000 families in the $\mathrm{PRC}$ and become the first nationally renowned trademark in the PRC property industry. In the context of global economic crisis, Vanke's 2008 annual report announced that the net profit had reduced by $17 \%$ compared with the year 2007 (China Vanke Co., Ltd., 2007; China Vanke Co., Ltd., 2008). Obviously, most of the developers are faced with terrible external environment, for example, the broken capital chain for REEs. Financial risk concerns brought about worries to the managers of REEs. They started to ask themselves, such as "What is the competitive status of our enterprise", and "What do we need to do to improve the competitiveness of our company"? The fivestep model-procedure mentioned above can help answer these questions in a systematic and hands-on way. Based on the annual reports (1989-2008) of Vanke and the interviews, the details and explanations of the case study can be discussed in the following section.

\section{Step 1: To understand general competi- tiveness indicators for China Vanke}

By adopting the indicator approach (IA), the relevant competitiveness indicators for assessing real estate firms are identified. This approach helps to present a list of general sample indicators for Vanke, including Land resources, Corporate governance, Innovation technology, Capital (financial ability), Integrated capability, Brand, Housing product, which 
have been identified in Table 1. In the process of identifying competitiveness indicators for China Vanke, a typical competitiveness indicator list suitable for Vanke can be obtained with special consideration to its growth characteristics and strategies. The proper understanding on the competitiveness indicators for REEs is the key to effectively measuring the business competitiveness.

\section{Step 2: To select the core competitiveness indicators for China Vanke}

Based on the general understanding of the indicators for assessing organizational competitiveness, this step is to select the core indicators for competitiveness assessment by considering the characteristics of China Vanke and its market environment in China. In applying this method, the index value for each competitiveness indicators can be generated through a series of face-to-face interviews with the divisional managers within Vanke Company. The final prioritized key indicators are shown in Table 3.

For example, Vanke first put forward the standardized production mode for housing product, also named as industrial production mode, and the organization intends to introduce factory production methods to real estate industry. This new mode helps transform the traditional house-building into car manufacturing mode (Wang et al., 2007). The typical understanding and practices of Vanke's housing industrialization can be summarized as 'Standardization, industrialization, assemblage and industrial chain integration.' The investigation to this organization suggests that this car manufacturing mode has greatly reduced the construction cost, and it helps Vanke gain its interregional scale advantages. Using this KCIs assessment tool, this innovative industrialization road has been identified and become one of the particular competitiveness indicators for China Vanke. Hence force, KCIs model provides a tool for conducting the identification of the indicators suitable to Vanke, which will help organizational decision-makers identify where they have core competences.

\section{Step 3: To understand the sources for Chi- na Vanke's competitiveness}

Having understood the key indicators for assessing Vanke's competitiveness, the decision-makers in the organizations can examine what level of key competitiveness the organization have, and where this competitiveness exist in the organizations. Investigating the sources of competitiveness is a very important

Table 3. The Key competitiveness indicators for China Vanke

\begin{tabular}{ll}
\hline Dimensions & Indicators \\
\hline $\mathrm{A}_{1}$ - Resources and scale & $\mathrm{A}_{11}$ - Moderate land reserves \\
& $\mathrm{A}_{12}-$ Sufficient funds and labor resources \\
$\mathrm{A}_{2}$ - Corporate governance & $\mathrm{A}_{21}$ - Mature corporate governance structure \\
& $\mathrm{A}_{22}$ - Moderate ownership balance \\
$\mathrm{A}_{3}$ - Inimitable operation strategy & $\mathrm{A}_{31}-$ Fast capital operation capability \\
& $\mathrm{A}_{32}-$ Standardized production mode (Industrial production mode) \\
& $\mathrm{A}_{33}$ - The nation-wide network expanding strategy(“3+X”) \\
& $\mathrm{A}_{34}-$ Flexible marketing capability \\
& $\mathrm{A}_{35}$ - Persistent innovation mechanism \\
& $\mathrm{A}_{41}$ - Unique Branding mechanism \\
$\mathrm{A}_{4}-$ Branding capability & $\mathrm{A}_{43}-$ Influential corporate culture \\
& $\mathrm{A}_{43}$ - Unique entrepreneurship \\
\hline
\end{tabular}


step in the process of competitiveness identification (Lu and Mou, 2006). The value chain method (VCM) and Portfolio matrix model (PMM) can be used to help identify the areas or activities within a real estate enterprise where the enterprise's core competitiveness exists. Using these methods leads to presenting a chain model for a real estate enterprise's core competitiveness in two fields, namely, primary activities and support activities. Following this road map, with referring to the key competitiveness indicators selected in the previous step, the decision-makers in Vanke can explore where the key competitiveness exists. For example, in the interview discussions with the Vanke's regional business managers in Tianjin, the successful operation of two projects relies on different competitive aspects in the whole process of Value Chain model (See Figure 4). During the Land reserve stage, Vanke won the project resources more and more depending on cooperation so as to improve the funds operation capability. For example, Vanke cooperated with the Teda group in obtaining the land area in the core region of Tianjin seaside development zone, considering Teda group's rich financial strength. By adopting this value chain perspective, it can be seen that Vanke's competitiveness came from its housing industrialization mode and good resource integrity ability. Meanwhile, in the marketing phase, Vanke adopted customer oriented strategy by increasing the accuracy of customers' needs. Besides, most of Vanke's projects, such as the Wonderland and Golden garden projects, the design, construction, property management (After sale services) chains were delivered to the scrutinized specialized companies for completing the value gaining of the rest of business activities. This approach helps Vanke control the numbers of employees and operation fees at a reasonable level while at the same time expand its development scales across various regions all over China. It can be seen from this part, the specialized operation capability and corporate management control were the inimitable competitiveness for Vanke.

\section{Step 4: To evaluate the competitiveness level for China Vanke}

This step involves quantitative analysis in order to present a value for indicating the level of competitiveness. Several techniques can be used for this purpose, such as KCIs model, WM model. For example, WM model is a competitiveness index model (Lin et al., 2001). It helps a real estate firm understand its competitiveness at a particular point of time. The model is written as:

$$
f(t)=k \cdot \lambda^{2} t \cdot \exp \left(-p \cdot(\lambda t)^{2}\right)
$$

where: $t$ is a particular time; $f(t)$ is the level of enterprises' competitiveness at the moment

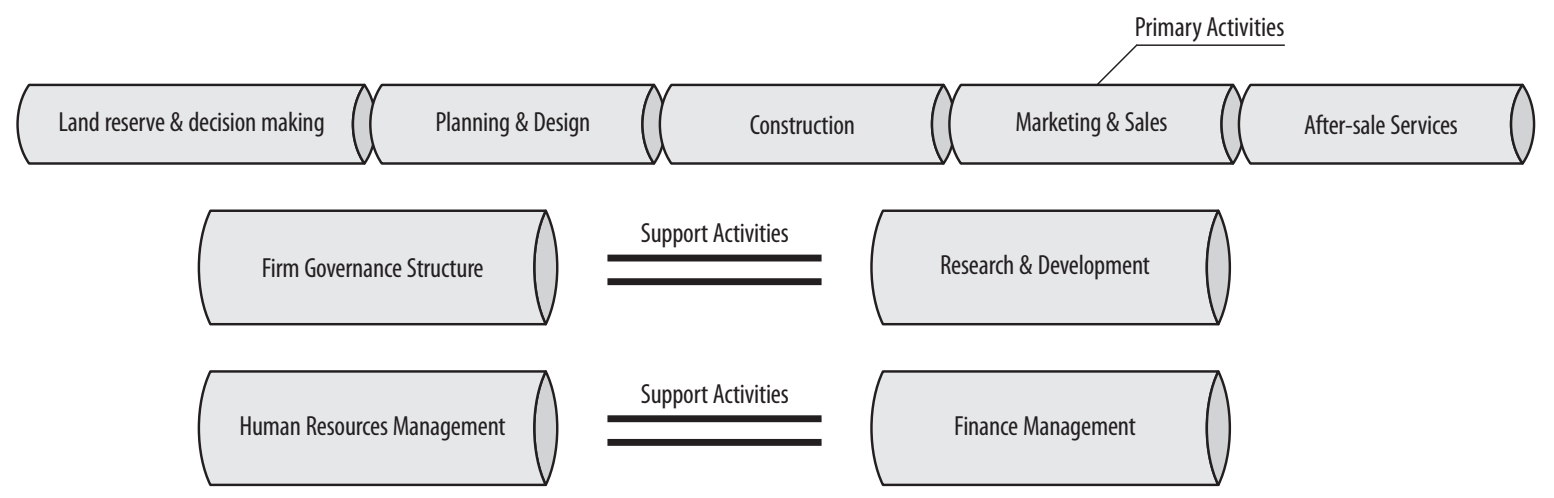

Figure 4. The value chain model (VCM) for REEs 
of " $t$ "; $p, k$ and $\lambda$ are parameters reflecting the performance of the competitiveness of enterprises.

For example, given the fast growth period of Vanke as " $t$ ", the core competitiveness indicators obtained by step 2 is " $p$ ", $k$ and $\lambda$ can be given by considering the typical weighted parameters, and the competitive level at the fast growth period can be evaluated afterwards.

\section{Step 5: To identify strategy for improving competitiveness for China Vanke}

After evaluating the competitiveness level, the organization Vanke would be keen to know how to improve its competitiveness in order to gain better competitiveness. The enterprise model method (EM) can be adopted to assist Vanke in identifying its strategy for improving competitiveness. EM is an effective tool for examining organizational resources across business activities and grasping the core competitive indicators. The application of EM model to Vanke real estate can be exhibited in Figure 5. It can be seen that Vanke's competitiveness is attributed by the major processes including land reserve, planning and design, construction, and post-sales service. Therefore, the strategy of improving Vanke's competitiveness should target to improve the performance of these processes. On the other hand, these processes are implemented through a number of functional sections mainly including $R \& D, H R$, finance, and marketing. These functional departments will affect directly the performance of various business processes. Thus, according to EM model, another important strategy is to evaluate the performance of various individual functions, and actions may be needed for ensuring that these functions are effective and work coordinately towards the organizational goals. In the interviews with business manager of Vanke's Hangzhou branch, it reveals the benefits of using EM to help the organization in finding out the strategy of improving the competitiveness in human resources department. It was found that the Hangzhou Branch Office of Vanke needs to employ more contract management experts in HR department to cope with increasing number contract disputes related risks in the real estate market environment. It can be seen that using EM approach can help identify proper strategy of allocating organizational resources in effective way in order to improve Vanke's competitiveness.

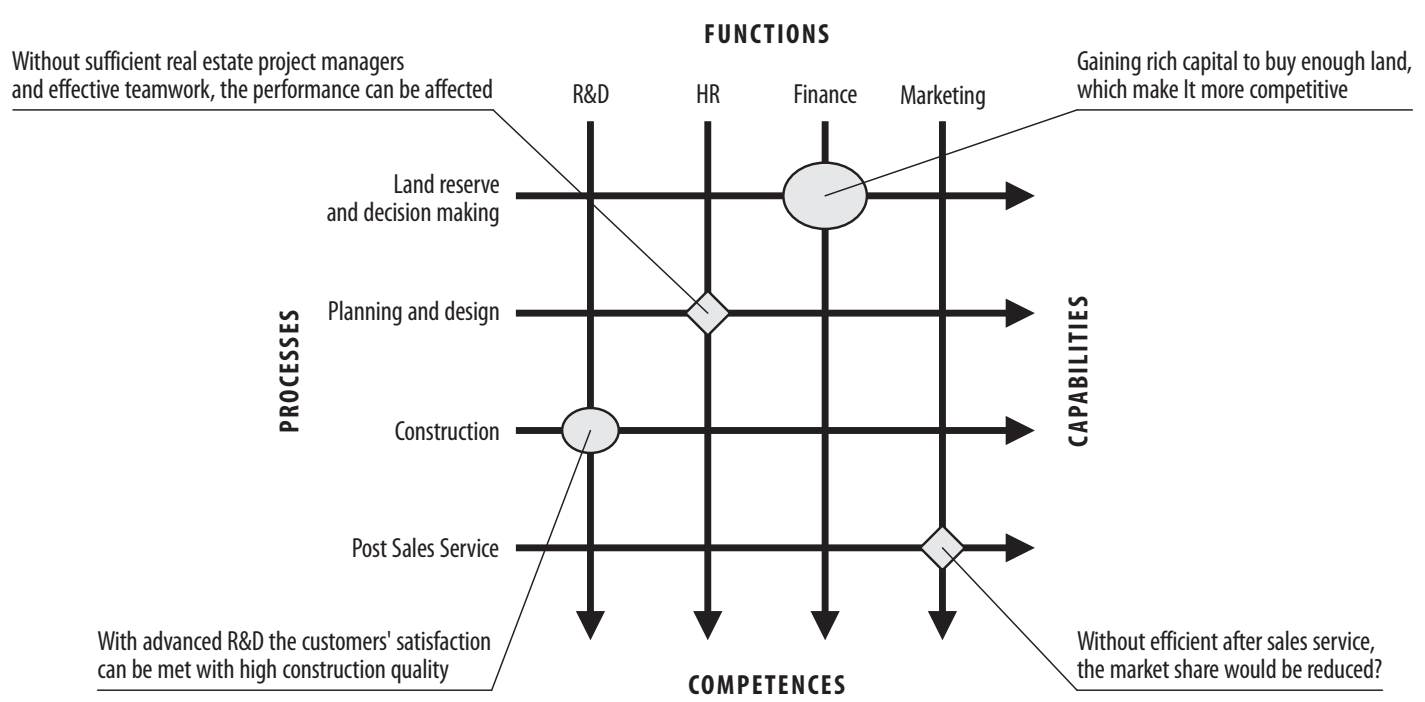

Figure 5. The enterprise model (EM) in application for REEs 


\section{CONCLUSION}

This research examines the applicability of the typical methods established for addressing organizational competitiveness in the Chinese real estate industry. It has been found that some of these methods are effectively applicable, some are applicable and some not applicable according to the characteristics of real estate industry and comments of the interviewees. This research offers the suggestions of how to use these different assessment approaches more effectively through a modelprocedure applied with a case study.

Assessing the competitiveness for real estate enterprises is a complicated process due to the special characteristics of this type of organization. Real estate firms are capital-intensive, location preferred, and full of risks. With embodying these characteristics, real estate enterprises need a different methodology to assist them in assessing their competitiveness. And such methodology is presented in this paper as the model-procedure for assessing a real estate organization's competitiveness. The model-procedure employs various existing competitiveness assessment methods in different processes. It can guide the process of competitiveness evaluation. Furthermore, the model-procedure brings together assessment approaches that can measure distinctly different processes in a structured model. The application of the model has been demonstrated through a case study of China Vanke, which involves constructive discussions with professionals and managers in Vanke. Although the data used are collected in China, the study provides valuable references for studies in examining different types of REEs' competitiveness in other overseas market environments. Further empirical studies on real estate competitiveness will be conducted by the research team in the future.

\section{REFERENCES}

Barrett, S., Stewart, M. and Underwood, J. (1978) The land market and development process, Occasional Paper No. 2, School for Advanced Urban Studies, University of Bristol.

Bogner, W.C., Thomas, H. and McGee, J. (2002) Competence and competitive advantage: towards a dynamic model, British Journal of Management, 10(4), pp. 275-290.

Chiang, T.A. and Trappey, A.J.C. (2007) Development of value chain collaborative model for product Life cycle management and its LCD industry adoption, International Journal of Production Economics, 109(1-2), pp. 90-104.

China Vanke Co., Ltd. (2007) 2007 annual report. [Online] China Vanke Co., Ltd. Available at: http://www.vanke.com/main/Web/Article/200 8/03/21/1835213757C62868.aspx [accessed 21 March 2008]

China Vanke Co., Ltd. (2008) 2008 annual report. [Online] China Vanke Co., Ltd. Available at: http://www.vanke.com/main/UpFiles/ Attach/9653/2009/04/13/1941531567.doc [accessed 13 April 2009]

Cong, Q. and Wang, Y.M. (2004) Analysis of several issues upon the human resource management of real estate enterprise, Tian Fu New Idea, 119(5), pp. 141-142. (In Chinese)

Committee of Donor Agencies for Small Enterprise Development (1995) Micro and small enterprises finance: guiding principles for selecting and supporting intermediaries, Research report, Washington D.C.

Drew, D.S. and Skitmore, R.M. (1997) The effect of contract type and size on competitiveness in bidding, Construction Management and Economics, 15(5), pp. 469-489.

Feurer, R. and Chaharbaghi, K. (1994) Defining competitiveness: A holistic approach, Management Decision, 32(2), pp. 49-58.

Hatten, K.J. and Rosenthal, S.R. (1999) Managing the process-centred enterprise, Long Range Planning, 32(3), pp. 293-310.

Hax, A.C. and Majluf, N.S. (1983) The use of the industry attractiveness-business strength matrix in strategic planning, Interfaces, 13(2), pp. 54-71.

Healey, P. (1994) Urban policy and property development: the institutional relations of real estate development in an old industrial region, Environment and Planning A, 26(2), pp. 177-198. 
Hobbs, B.F. and Meier, P. (2000) Energy Decisions and the Environment: A Guide to the Use of Multicriteria Methods, Kluwer Academic Publishers, Boston.

Hulshoff, H.E., Kirchhoff, J.J., Kirchhoff, B.A., Walsh, S.T. and Westhof, F.M.J. (1998) "New services" strategic study and exploratory survey of a dynamic phenomenon, EIM Small Business Research, Zoetermeer, Netherlands, 11/1998.

Huang, X.M. and Wu, Y.Z. (2005) The landlord of Hangzhou: Green Town, The real estate Herald in China and abroad, Z1, pp. 10-12.

IMD (2004) World Competitiveness Yearbook 2003, IMD International, Lausanne, Switzerland.

Jansen, R.C. (1992) A general mixture model for mapping quantitative trait loci by using molecular markers, Theoretical and Applied Genetics, 85(2-3), pp. 252-260.

Jin, S. (2003) Analysis on the particularity of real estate development enterprises' accounting, $\mathrm{Fi}$ nance and Accounting Monthly, 23, pp. 20-21. (In Chinese)

Lin, D.J., Yin, C.Y. and Lin, Y.X. (2001) Enterprises' competitiveness evaluation based on functional modeling and analysis, Journal of Capital University of Economics and Business, 3, pp. 14-18. (In Chinese)

Liu, W.X. (2004) The background of the levy on property tax and its impact upon the real estate development and consumption, China Real Estate Finance, 5, pp. 3-6. (In Chinese)

Lu, L.K. and Mou, S.Q. (2006) Build the core competitiveness of real estate enterprises, Real estate information of China, 5, pp. 50-51. (In Chinese)

Macmillan, H. and Tampoe, M. (2000) Strategic Management: Process, Content, and Implementation, Oxford University Press, New York.

Mao, R.R. (2007) The benchmark of China s real estate-VANKE s brand development strategy, Journal of Shanghai Jiaotong University, 41(S1), pp. 548-551.

Oral, M. (1993) A methodology for competitiveness analysis and strategy formulation in glass industry, European Journal of Operational Research, 68(1), pp. 9-22.

Porter, M.E. (1990) The Competitive Advantage of Nations, The Free Press, New York, NY.

Porter, M.E. and Millar, V.E. (1985) How information gives you competitive advantage, Harvard Business Review, 63(4), pp. 149-160.
Rappaport, A. (1983) Corporate performance standards and shareholder value, Journal of Business Strategy, 3(4), pp. 28-38.

Shen, L.Y., Lu, W.S. and Yam, M.C.H. (2006) Contractor key competitiveness indicators: a China study, Journal of Construction Engineering and Management-ASCE, 132(4), pp. 416-424.

Sirikrai, S.B. and Tang, J.C.S. (2006) Industrial competitiveness analysis: Using the analytic hierarchy process, The Journal of High Technology Management Research, 17(1), pp. 71-83.

Tay, J.Y.W. and Tay, L. (2007) Market orientation and the property development business in Singapore, International Journal of Strategic Property management, 11(1), pp. 1-16.

van der Krabben, E. and Lambooy, J.G. (1993) A theoretical framework for the functioning of the Dutch property market, Urban Studies, 30(8), pp. 1381-1397.

Walsh, S.T. and Linton, J.D. (2001) The competence pyramid: A framework for identifying and analyzing firm and industry competence, Technology Analysis \& Strategic Management, 13(2), pp. 165-177.

Wang, Z.J., Wang, X.X. and Li, Y.H. (2007) Business Model Innovation in China's Real Estate Industry: the Case of Shenzhen Vanke. In: International Conference on Wireless Communications, Networking and Mobile Computing, 2007. WiCom 2007. [Online] Available at: http://ieeexplore.ieee.org/stamp/stamp. jsp?tp $=$ \&arnumber $=4340813$

Weibull, W. (1951) A statistical distribution function of wide applicability, Journal of Applied Mechanics-Transactions of the ASME, 18, pp. 293-297.

Weimer, A.M. and Hoyt, H. (1939) Principles of Urban Real Estate, The Ronald Press Co., New York.

Wernerfelt, B. (1984) Resource-based view of the firm, Strategic Management Journal, 5(2), pp. 171-180.

Wu, S.W. (2002) Discussion upon the real estate developer's external financing modalities, Hainan Finance, 5, pp. 45-47. (In Chinese)

Zhang, C. (2007) Research on China's current situation and countermeasures of foreign investment utilization in real estate enterprises, China Real Estate Finance, pp. 31-34. (In Chinese) 


\title{
NEKILNOJAMOJO TURTO İMONIŲ KONKURENCINGUMO IQVERINIMAS KINIJOJE: PROCEDŪROS MODELIS
}

\author{
Xiaoling ZHANG, Liyin SHEN, Yuzhe WU, Linda C. N. FAN
}

Nuo 2001 metu, kai Kinija tapo Pasaulinès prekybos organizacijos (PPO) nare, ir vietinès, ir užsienio nekilnojamojo turto imonès gali konkuruoti tomis pačiomis rinkos salygomis. Dėl to konkurencija Kinijos nekilnojamojo turto rinkoje tapo tik aršesnè. Ši iššūki būtina suprasti, nes jis nekilnojamojo turto įmonèms leidžia tinkamai ivvertinti savo konkurencinguma, prisitaikyti prie konkurencinès aplinkos bei pasirinkti adekvačius metodus konkurencingumui didinti. Straipsnyje apžvelgiama, kaip suprantamas izvairiu pripažintų konkurencingumo vertinimo metodu tinkamumas. Pateikiamos Kinijos nekilnojamojo turto imoniu charakteristikos. Remiantis atlikto tyrimo rezultatais, nekilnojamojo turto sektoriaus charakteristikomis ir apklausoje dalyvavusiu asmenų komentarais, nagrinejamas i̇vairiu pripažintų konkurencingumo vertinimo metodu tinkamumas Kinijoje veikiančioms nekilnojamojo turto organizacijoms. Suvokiant ši tinkamuma, galima sukurti procedūros modelị, kurị naudojant būtų vertinamas nekilnojamojo turto įmonių konkurencingumas. Ivairiais nekilnojamojo turto įmonių konkurencingumo tyrinejjimo proceso etapais taikant procedūros modeli naudojami skirtingi vertinimo metodai. Minèto modelio taikymo efektyvumas aptariamas su šios srities profesionalais. Tada pateikiamas konkretaus atvejo, parodančio procedūros modelio taikyma, tyrimas, o jo išvados suteikia vertingos informacijos, kuria galima naudoti tyrinėjant konkurencingumo vertinima kitos šalies nekilnojamojo turto sektoriuose. 